\title{
PEMISAHAN ANOMALI GAYABERAT DAERAH LAMPUNG MENGGUNAKAN BIDIMENSIONAL EMPIRICAL MODE DECOMPOSITION (BEMD)
}

\section{GRAVITY ANOMALY SEPARATION IN LAMPUNG \\ REGION USING BIDIMENSIONAL EMPIRICAL MODE DECOMPOSITION (BEMD)}

\author{
Gestin Mey Ekawati \\ Institut Teknologi Sumatera; JI. Terusan Ryacudu, W ay H ui, Kecamatan Jati Agung, Lampung Selatan \\ 35365; (0721) 8030188
}

Received: 2021, August 24

Accepted: 2021, October $26^{\text {th }}$

\section{Keywords:}

BEMD;

Filtering;

Gravity;

Regional;

Residual.

\section{Corespondent Email:}

gestin@tg.itera.ac.id

\section{H ow to cite this article:}

Ekawati, G.M. (2021).

Pemisahan Anomali

Gayaberat Daerah Lampung

M enggunakan Bidimensional

Empirical Mode

Decomposition (BEMD).

Jurnal G eofisika Eksplorasi,
A bstrak. M etode gayaberat adalah salah satu metode geofisika yang digunakan dalam eksplorasi mineral dan migas. Metode ini memanfaatkan percepatan gravitasi untuk memodelkan struktur densitas batuan di dalam bumi, mendeliniasi struktur maupun satuan geologi. Pada tahap pengolahan data gayaberat diperlukan beberapa koreksi untuk menghasilkan anomali Bouguer lengkap (CBA). Nilai CBA merupakan hasil resultan dari seluruh kontribusi massa di bawah permukaan dan di sekitar titik datum. Pemisahan anomali CBA menjadi regional dan residual menjadi tahap penting dalam interpretasi dan pemodelan gayaberat. Beberapa metode pemisahan anomali yang ada saat ini sudah menunjukkan hasil yang baik. Pada prinsipnya, metode tersebut menggunakan teknik fitting permukaan, pemfilteran frekuensi, smoothing pada domain spasial, atau kontinyuasi medan. Namun, metode tersebut memiliki aspek subjektif yang tinggi dalam menentukan parameter yang bekerja. Pada paper ini, saya mengaplikasikan metode alternatif yaitu Bidimensional Empirical Mode Decomposition (BEMD) pada daerah Lampung. BEMD menganalisis data secara algoritmik dan mampu mendekomposisi data secara empirik yang dapat diasosiasikan dengan pemisahan anomali pada metode gayaberat. Keuntungan utama metode ini adalah kemampuannya untuk memberikan pemisahan yang hampir sempurna antar anomali yang terdapat dalam data gayaberat. Metode ini mampu secara langsung menunjukkan anomali yang dicari sehingga pemilihan anomali target dapat dilakukan dengan mudah karena jumlah dekomposisinya yang tidak banyak.

Abstract The gravity method is one of the geophysical methods that is used in 
07(03), 191-201.

C 2021 JGE (Jurnal Geofisika Eksplorasi). This article is an openaccess article distributed under the terms and conditions of the Creative Commons Attribution (CC BY NC) mineral exploration as well as in petroleum exploration. This method measures gravity acceleration to model the subsurface structure of rock density, delineate structural and geological units. In gravity processing steps, some corrections are made to obtain a Complete Bouguer Anomaly (CBA). The value of CBA is the resultant of all the masses beneath and near the datum point. Separation of anomalies into the regional and the residual from the CBA is considered an essential step for interpretation and gravity modeling. There are exists some satisfactory methods to do such separation. In principle, they use surface fitting, frequency filtering, spatial domain smoothing, or field continuation. However, at some point, these methods inherit some subjective analysis to derive filter parameters. This paper applies an alternative method, namely Bidimensional Empirical Mode Decomposition (BEM D) in the Lampung region. It decomposes data empirically that can be associated with anomaly separation. The main advantage of this method is its ability to give a near-complete separation of the gravity anomalies. The target anomalies can often be recognized directly; thus, one can easily choose from a few anomalies.

\section{PENDAHULUAN}

Metode gayaberat merupakan salah satu metode geofisika yang sering digunakan untuk eksplorasi sumber daya alam seperti minyak dan gas bumi, panas bumi, maupun tambang mineral. Dalam pengukuran gayaberat, parameter objek yang diukur adalah percepatan gayaberat dalam satuan miliGal $\left(10^{-5} \mathrm{~m} / \mathrm{s}^{2}\right)$. Setelah mendapatkan nilai percepatan gayaberat maka dilakukan berbagai koreksi untuk mendapatkan nilai Complete Bouguer Anomaly (CBA) yang mencerminkan variasi geologi bawah permukaan. Nilai CBA merupakan gabungan antara anomali regional dan residual sehingga proses pemisahan anomali gayaberat CBA menjadi tahap yang sangat penting dalam proses pengolahan, interpretasi maupun pemodelan struktur bawah permukaan yang berhubungan dengan kontras densitas batuan di bawah permukaan (Gambar 1). Pengolahan dan interpretasi pada anomali residual diperlukan untuk tujuan eksplorasi sumber daya alam yang berhubungan dengan kondisi geologi dekat dengan permukaan atau anomali dangkal.

Kompleksitas dari struktur geologi dan kontras densitas bersama-sama berkontribusi pada data gayaberat yang kompleks. Data gayaberat observasi yang diukur di permukaan bumi adalah resultan (penjumlahan) dari keseluruhan tubuh anomali di bawah permukaan bumi yang salah satunya berkaitan dengan target anomali. Target anomali itu disebut dengan anomali residual. Anomali residual ini berkaitan dengan adanya bodi yang berada di kedalaman yang dangkal. Target anomali residual perlu dipisahkan dari anomali lainnya seperti anomali regional dan noise (Telford dkk., 1990). Noise memiliki periode fluktuasi anomali lebih pendek daripada residual sedangkan regional lebih lama periode fluktuasinya.

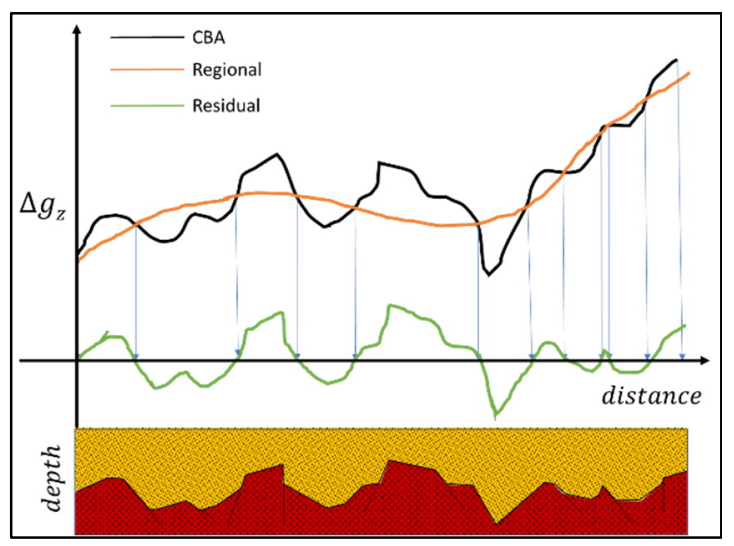

Gambar 1. Ilustrasi penghapusan trend lokal untuk pemisahan anomali residual dan regional. 
M etode pemisahan anomali (filtering) yang umum digunakan dalam pengolahan data gayaberat menghasilkan hasil yang baik, namun semua metode ini membutuhkan interaksi manusia untuk mendapatkan filter parameternya sehingga akan memperoleh hasil yang tidak unik dan berbeda pada setiap pengolah datanya (different user). M etode moving average menggunakan fix window untuk pengolahan data gayaberat keseluruhan tetapi kenyataannya pada data real, kita tidak dapat mencocokkan data dengan hanya satu single ukuran window karena beragamnya panjang gelombang yang terkandung dalam data dan perbedaan pengolah data memungkinkan perbedaan pada hasil pemisahan anomali yang diperoleh. Metode polinomial dikontrol oleh derajat polinomial yang dipilih oleh user. Metode Gaussian menggunakan nilai cut-off bilangan gelombang (k) yang ditentukan oleh user. Metode kontinuasi juga sangat bergantung dengan pemilihan besarnya pergeseran elevasi yang akan dilakukan. Seluruh metode tersebut membutuhkan analisis yang tidak sederhana untuk menentukan parameter yang tepat untuk mendapatkan anomali yang menjadi target.

Sebuah metode alternatif disebut Empirical Mode Decomposition (EMD) dikembangkan oleh Huang dkk. (1971) untuk membangun teknik dekomposisi multiresolusi. EMD memiliki kemampuan dekomposisi yang adaptif dan dalam bidang geofisika, EM D telah diterapkan pada data seismik (Battista dkk., 2007; Han \& Van der Baan, 2013) dan juga untuk evaluasi log (H uang \& M ilkereit, 2009). EMD adalah analisis data untuk satu dimensi sedangkan data anomali gayaberat merupakan data dua dimensi. Konsep dari EMD diimplementasikan untuk menganalisis sinyal dua dimensi berupa gambar dan peta yang disebut Bidimensional Empirical Mode Decomposition (BEMD) (Linderhed, 2002; Nunes dkk., 2003). Bidimensional Empirical
M ode Decomposition (BEM D) diusulkan untuk dapat melakukan pemisahan anomali medan potensial geofisika. Huang dkk., (2010) menggunakan BEMD untuk mengekstraksi anomali gayaberat berasosiasi dengan mineralisasi emas pada lapangan emas Tongsi. (Al-Rahim, 2016) menggunakan metode BEMD untuk melakukan pemisahan lapangan gayaberat di Irak. Firdaus dan Ekawati (2016) juga telah mengaplikasikan metode ini untuk memisahkan anomali gayaberat global di seluruh permukaan bumi dari anomali kerak dan trend regionalnya. Aplikasi EMD juga diterapkan pada data gayaberat ai rbone ( $\mathrm{H}$ asan \& Pierce, 2008).

Studi komparatif metode BEMD dengan metode pemisahan anomali lainnya (trend surface analysis dan wavelet filtering) telah dilakukan oleh Mandal dkk. (2017). Studi tersebut menyimpulkan bahwa hasil metode BEMD ini dapat mengatasi keberadaan bising pada data sehingga dinilai lebih cocok untuk diterapkan pada data lapangan.

\section{DASAR TEORI}

Prinsip dasar BEMD diperoleh dari hasil penelitian Cooper dkk. (2010) yaitu Empirical M ode Decomposition (EMD) sebagai alat baru untuk pemisahan medan potensial dan penelitian mengenai pemisahan anomali gayaberat menggunakan ekstensi EMD menjadi dua dimensi yang disebut Bidimensional Empirical Mode Decomposition (BEMD) (Pei dkk., 2012). Metode BEMD dirancang untuk mengurangi sifat nonstasioner dari sinyal multikomponen menjadi serangkaian amplitudo lokal dan kontribusi modulasi frekuensi (AM-FM). Proses ini menggunakan teknik sifting yang bertujuan untuk mendapatkan basis dekomposisi yang memiliki rerata lokal nol. Sinyal diuraikan menjadi satu set fungsi basis yang adaptif dan diberi nama Intrisic Mode Function (IMF). BEM D tidak memiliki basis apriori yang harus diasumsikan sebelumnya. 
Inilah yang membedakannya dengan metode analisis Fourier yang mengasumsikan basis berupa gelombang harmonik. Selain itu, karakteristiknya dalam menganalisis data secara lokal juga menjadikannya unggul dalam segi resolusi dari seluruh metode yang sudah ada saat ini. Oleh karena itu, metode ini dapat dengan mudah menangani data yang sangat non-linier dan non-stasioner. Sinyal kompleks apapun dapat diuraikan menjadi hanya beberapa IMF saja tanpa adanya kehilangan atau distorsi informasi.

Asumsi dasar yang digunakan metode ini berlandaskan pada bahwa setiap kumpulan data pada dasarnya terdiri dari superimposisi dari sejumlah terbatas modulasi osilasi sederhana yang disebut IMF. IMF adalah sinyal yang memiliki rerata lokal nol dan merupakan sinyal monokomponen. Dengan demikian, karakteristik utama IMF adalah memiliki jumlah zero-crossings yang sama dengan titik-titik ekstremanya (atau hanya berbeda paling banyak satu) dan juga simetris terhadap absis puncak berkaitan dengan local mean. Kriteria ini digunakan dalam proses sifting untuk menghapus trend lokal yang kuat. M eskipun penggunaannya sangat luas, BEM D masih belum dapat diformulasikan secara analitik dan prosesnya ditentukan oleh sebuah algoritma yang spesifik ( $\mathbf{G}$ ambar $\mathbf{2}$ ).

Jika terdapat sinyal real $g(x, y)$, BEMD mengaplikasikan algoritma berikut untuk mendapatkan satu set IM F :

a. Identifikasi semua eksterma dari $g(x, y)$.

b. Ekstraksi maksimum dan minimum lokal.

c. Interpolasi upper envelope dan lower envelope dari titik-titik ekstrimum lokal.

d. Perhitungan rerata lokal $m(x, y)$ di antara upper envelope dan lower envelope.

e. Ekstraksi detail, $d(x, y)=g(x, y)-m(x, y)$.

f. Jika rerata lokal $m(x, y)=0$, maka IMF diekstrak.

g. Iterasi pada residual $r(x, y)=g(x, y)-m(x, y)$.

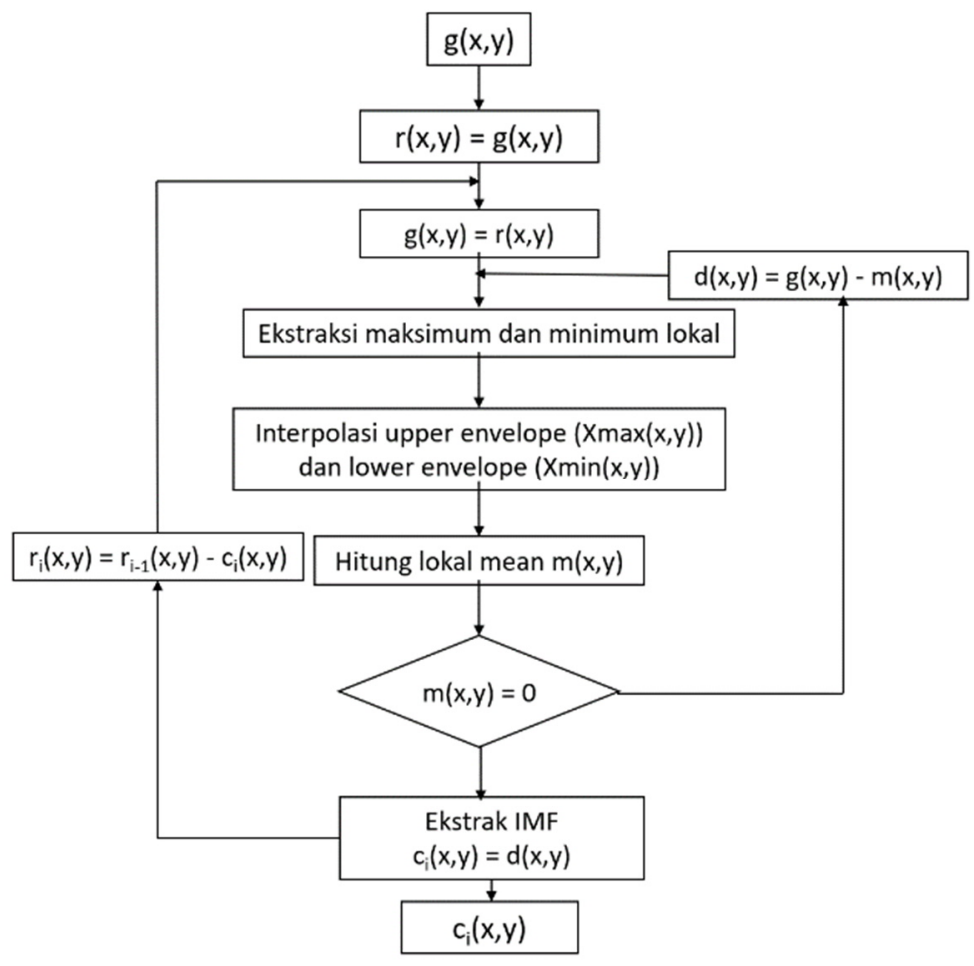

Gambar 2. Diagram alir algoritma BEMD. 
Dalam praktiknya, proses sifting (penyaringan) harus lakukan berulang, di mana langkah satu sampai empat diulangi sampai detailnya $d(x, y)$ bisa dianggap zeromean dan sesuai dengan kriteria definisi IM F. Detail yang memenuhi kriteria kemudian menjadi IMF pertama dan dikurangkan dari data aslinya kemudian proses dimulai lagi. Oleh karena itu, sinyal $g(x, y)$ dapat dinyatakan sebagai :

$$
g(x, y)=\sum_{i=1}^{k} c_{i}(x, y)+r(x, y)
$$

dimana i menyatakan indeks untuk IMF $\left(c_{i}\right)$ dan $r$ adalah trend global dari $\mathrm{g}(\mathrm{x}, \mathrm{y})$.

Saat menggunakan analisis BEM D, jumlah iterasi sifting, kriteria penghentian (stopping criteria) dan teknik interpolasi envelope merupakan beberapa hal yang perlu dicermati. llustrasi proses sifting ditunjukkan pada

Gambar 3. Gambar tersebut mengilustrasikan bagaimana rerata lokal (permukaan berwarna kuning) dihitung melalui interpolasi titik-titik ekstrimum menjadi permukaan upper envelope dan lower envelope. Objektif dalam sifting adalah membuat rerata lokal bernilai nol di mana-mana yang tentu pada prakteknya diperlukan suatu nilai toleransi tertentu (Gambar 4).

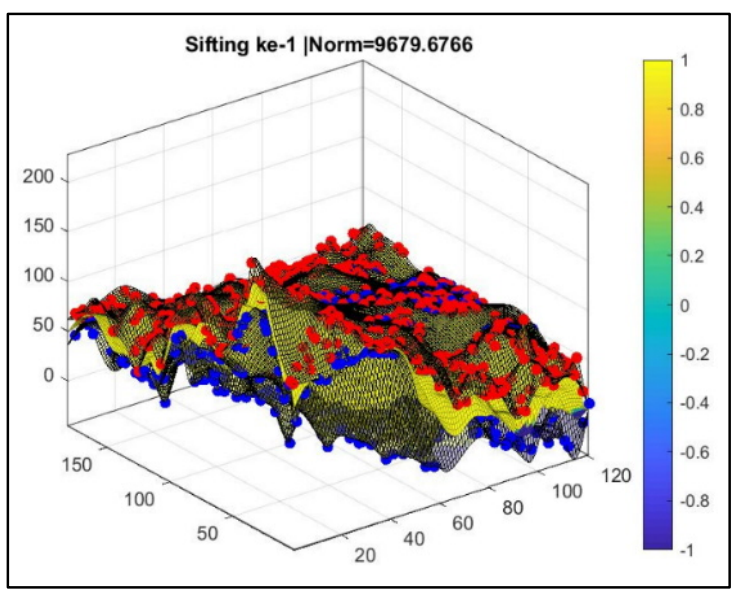

Gambar 3. Contoh proses sifting ke-1 untuk ekstraksi IMF 1. Rerata lokal dihitung. Dimana, titik merah adalah titik maksimum, titik biru adalah titik minimum, permukaan jaring adalah upper envelope dan lower envelope, sedangkan permukaan berwarna adalah rerata lokal.

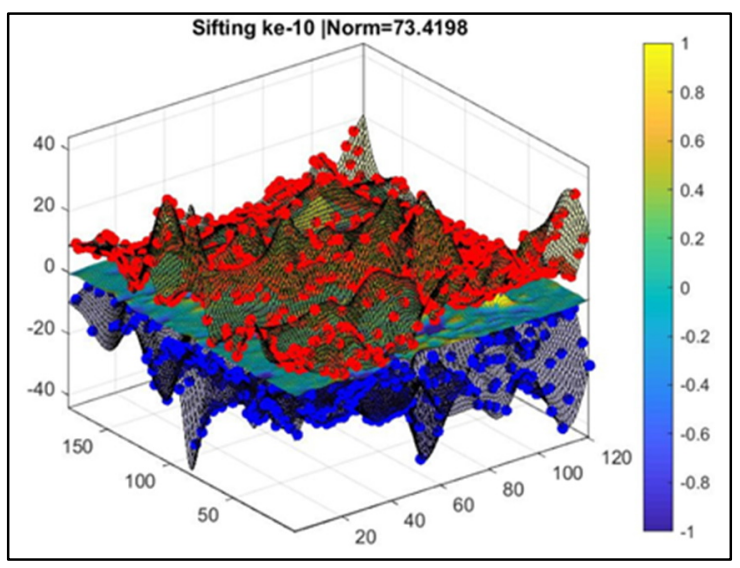

Gambar 4. Contoh proses sifting ke-10 untuk ekstraksi IM F 1. Pada iterasi ke-10 ini, rerata lokal dianggap sudah nol, sehingga IM F bisa diekstrak.

\section{METODE PENELITIAN}

Data gayaberat yang digunakan pada penelitian ini adalah Complete Bouguer Anomaly (CBA) di sekitar Provinsi Lampung, Indonesia. Lampung terletak di bagian paling selatan Pulau Sumatera. Ekstraksi data menggunakan koordinat daerah Lampung $103^{\circ} 48^{\prime}-105^{\circ} 45^{\prime}$ BT dan 3०45'-6 $45^{\prime}$ LS. CBA pada Gambar $\mathbf{5}$ diperoleh dengan melakukan koreksi Bouguer dan koreksi medan pada data grid Free Air Anomaly (FAA) yang dibuka untuk public (Sandwell dkk., 2014).

Data CBA memperlihatkan medan gayaberat yang memiliki rentang nilai anomali yang sangat besar (-60 s.d. 240 mgal). A nomali yang bernilai besar ini disebut sebagai anomali regional karena karakteristik utamanya yang memiliki panjang gelombang yang besar. Nilai CBA merupakan nilai total anomali gayaberat yang dipengaruhi oleh densitas batuan dari mantel bumi bagian atas sampai ke permukaan bumi.

Secara regional, dapat teramati pola sebaran anomali rendah berada hampir di seluruh bagian peta (warna biru-ungu), sementara anomali tinggi (warna kuning-merah) terdapat di barat daya daerah penelitian. Sementara itu, anomali kecil yang tersembunyi di dalam 
dominasi anomali regional tersebut dinamakan anomali residual. Anomali residual sering diasosiasikan dengan bodi anomali yang dangkal dan berukuran relatif kecil. Ini yang membedakannya dengan anomali regional yang sering diasosiasikan dengan bodi anomali yang besar. Tidak seperti anomali residual, anomali regional belum dapat dipastikan berasal dari tempat yang lebih dalam dari residual. Karena itu, anomali regional memiliki ambiguitas interpretasi yang lebih tinggi daripada anomali residual.

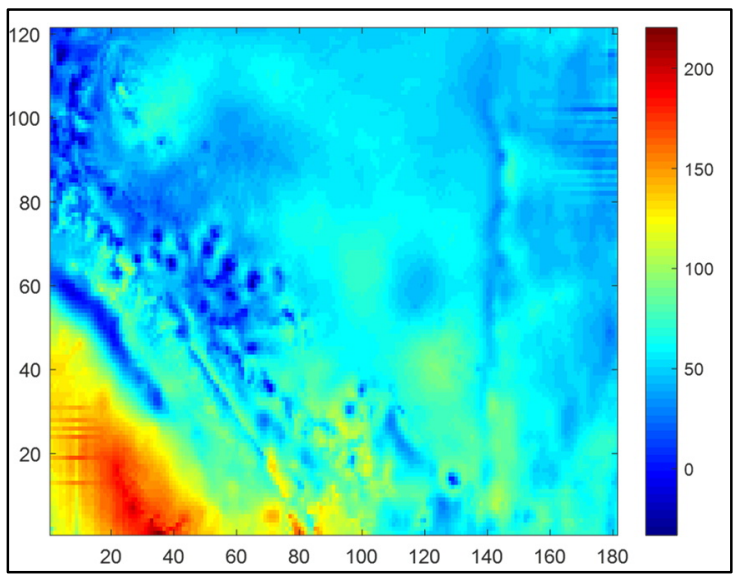

Gambar 5. Peta CBA Lampung dalam miliGal.

Penelitian ini dilakukan sesuai diagram alir yang ditunjukkan pada Gambar 6. Sebagaimana ditunjukkan pada diagram, penelitian ini terdiri dari beberapa tahapan mulai dari penentuan area studi sampai hasil akhir berupa peta anomali gayaberat setelah BEMD diterapkan. Seluruh nilai anomali dihitung secara konsisten menggunakan densitas referensi sebesar $2,67 \mathrm{~g} / \mathrm{cm}^{3}$. Penentuan IMF juga dilakukan dengan teliti untuk dapat memenuhi kriteria pemisahan anomali yang stabil. Jika teridentifikasi terdapat 2 IMF berdekatan yang memiliki karakter berpasangan yakni orde osilasinya sama tetapi terurai menjadi dua IMF, maka kedua IM F tersebut dianggap satu IM F yang mengalami over-dekomposisi.

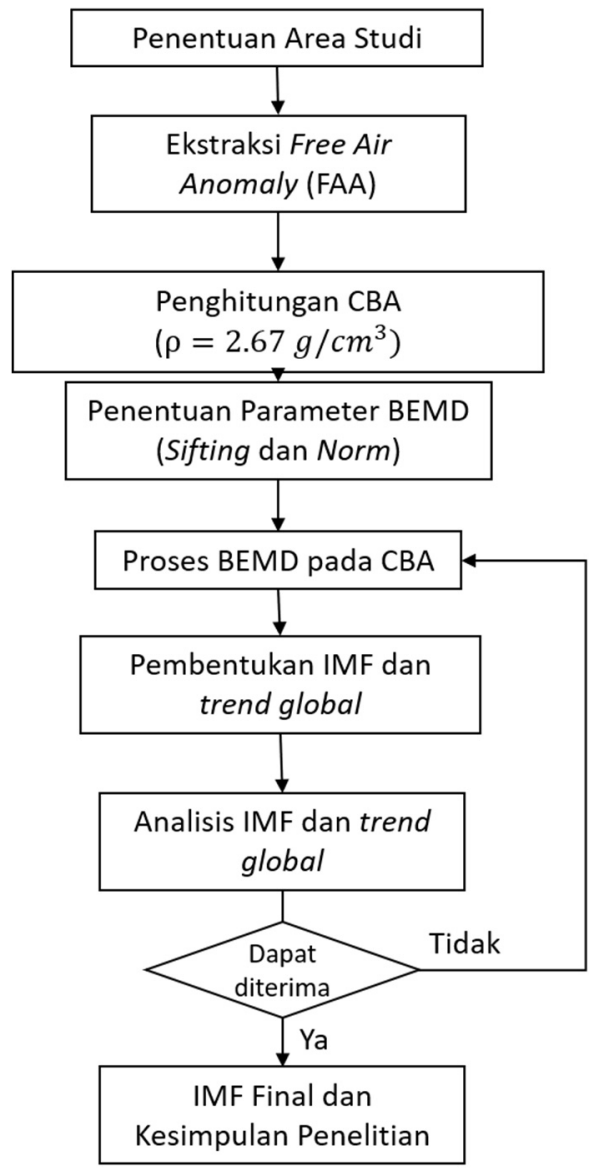

Gambar 6. Diagram alir penelitian.

\section{HASIL DAN PEMBAHASAN}

Dalam paper ini, metode BEM D digunakan untuk melakukan pemisahan anomali gayaberat CBA pada daerah Lampung. Algoritma BEM D menghasilkan sejumlah IM F yang memperlihatkan pemisahan anomali menurut level/tingkat osilasinya. Anomali yang memiliki panjang gelombang lebih kecil dipisahkan dari keseluruhan data untuk menjadi IMF pertama, lalu anomali dengan panjang gelombang pendek berikutnya dijadikan IMF selanjutnya. Proses tersebut bekerja tanpa interupsi dari pengolah data (user) dan tidak ada parameter atau kondisi yang mengendalikan proses pemisahan tersebut. Proses pemisahan ini tidak melibatkan window, fungsi basis, nilai cut-off, atau penentuan level yang subjektif. BEMD murni bekerja berdasarkan data tanpa 
melibatkan banyak campur tangan orang yang mengolah data.

M etode BEMD dapat memisahkan setiap anomali lokal dengan efektif dan detail. Data pada penelitian ini berhasil didekomposisi menjadi 5 buah IMF dan 1 trend global (Gambar 8-13). M asing-masing IM F diperoleh setelah maksimal 10 iterasi sifting. Lima IM F ini memenuhi kriteria IMF dimana rerata lokalnya nol, terlihat dari fluktuasi nilai anomalinya di sekitar level nol. Dengan kata lain, IMF tersebut sudah tidak memiliki trend lokal.

Setiap IM F menunjukkan ekspresi struktur intrinsik anomali yang unik dan tidak berulang pada IMF lainnya. Ini menunjukkan bahwa pemisahan anomali BEMD dilakukan secara tuntas dengan resolusi yang sangat tinggi. Total seluruh IMF dan trend globalnya akan kembali menghasilkan data aslinya. Ini membuktikan bahwa BEMD mendekomposisi secara lengkap dan tidak mengubah total energi pada sinyal sebelum dan setelah dekomposisi. BEMD hanya menguraikan energi tersebut dalam setiap IMF (Bekara \& $V$ an der Baan, 2009). Jumlah IMF yang dihasilkan bergantung dengan kriteria henti yang digunakan. Semakin kecil kriteria hentinya maka akan semakin intensif proses ekstraksinya sehingga akan menghasilkan penguraian (IMF) yang lebih banyak. Di sisi lain, biaya komputasinya akan semakin mahal namun lebih banyak struktur intrinsik yang akan disajikan.

Pengamatan yang lebih teliti memperlihatkan bahwa setiap IM F anomali itu menunjukkan detail struktur yang berbedabeda dan seluruhnya terambil dari data aslinya, tanpa terjadi distorsi dan kehilangan informasi. Proses yang dijalankan oleh BEM D bisa dianalogikan dengan proses moving average berulang dengan window lokal yang adaptif. Proses ekstraksi bertingkat ini serupa dengan teknik analisis dyadic filter bank ( $\mathrm{Ma}$ dkk., 2019). BEMD dirancang untuk mereduksi anomali yang multi-komponen dan non-linear menjadi serangkaian kontribusi anomali tunggal. Artinya, anomali dari suatu benda di bawah permukaan bumi dimunculkan sebagai sebuah anomali lokal. $\mathrm{H}$ asil pengolahan BEMD dapat menyajikan kedetailan dalam data yang tidak teridentifikasi dengan jelas dalam peta anomali biasa, tanpa perlu menentukan informasi sebelumnya tentang sifat alami dari sumber bodi anomali. Ini memperlihatkan keunggulan utama pemisahan anomali dengan BEMD dalam hal tingginya resolusi yang dihasilkan.

Secara intuitif, kita bisa melihat bahwa IM F secara efektif menampilkan karakter data. Osilasi lokal tercepat yang dikumpulkan di IMF 1 mewakili tingkat detail tertinggi dari data. M ode osilasi yang lebih rendah, semakin sedikit detail yang terkandung. $\mathrm{Hal}$ itu mudah diamati bahwa BEMD mengekstraksi osilasi yang tercepat yang terkandung dalam data dan disimpan sebagai IMF. Proses ini dilakukan secara berurutan sebagaimana ditunjukkan pada Gambar 7. IM F 1 bertindak sebagai highpass band dari data input sedangkan IMF 2 bertindak sebagai high-pass band dari IMF 1 , dan seterusnya. Fenomena ini menunjukkan perilaku BEMD sebagai dyadic-filter dengan tingkat osilasi yang mengalami overlapping. BEM D juga bisa dianalogikan sebagai sucessive reverse moving average dengan window lokal yang adaptif. Pada proses ini bisa dikatakan sebagai reverse (kebalikan) karena dalam moving average filtering, mode osilasi rendah yang dilewatkan, sementara pada BEMD melewatkan mode osilasi tinggi. Dengan demikian, setiap IMF adalah filter.

IMF diklasifikasi berdasarkan tingkat osilasinya. IMF 1 adalah IMF dengan orde tertinggi. Berdasarkan karakteristik tersebut, maka IMF kecil berasosiasi dengan noise dan anomali residual (dangkal) sementara IMF yang lebih besar berasosiasi dengan anomali yang lebih regional. Dari analisis struktur anomali ini, ambiguitas anomali residual dan 
regional sedikit berkurang sebab struktur anomali yang berasal dari satu tubuh geologi yang sama akan mudah diidentifikasi meskipun memiliki panjang gelombang yang berbeda (muncul di IMF yang berbeda). Batas kontur positif dan negatif mengindikasikan batas satuan geologi tertentu di bawah permukaan bumi.

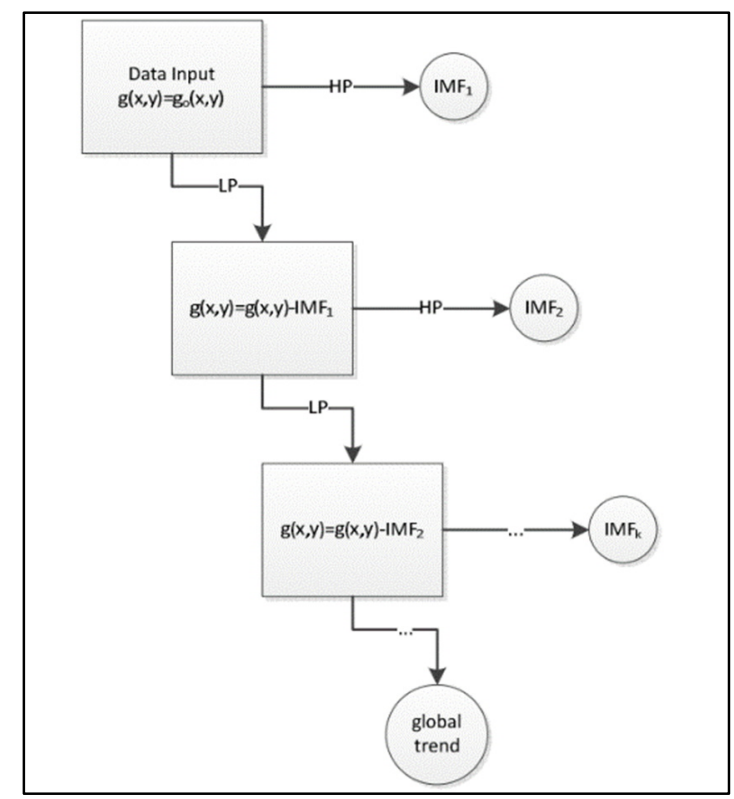

Gambar 7. Proses pemisahan anomali menggunakan BEMD mirip dengan dyadic-filter dan dianalogikan sebagai succesively reverse moving average dengan window adaptif. HP (High Pass Filter), LP (Low Pass Filter).

IMF 1 yang memiliki panjang gelombang terpendek berasal dari sumber anomali yang paling dekat dengan permukaan bumi dan berukuran relatif kecil. Sedangkan IM F 2 dan seterusnya memiliki gelombang lebih panjang dan diduga berasal dari sumber anomali yang lebih dalam dan atau berukuran lebih besar. IM F 6 adalah trend global dari data gayaberat sehingga disebut dengan anomali paling regional. Anomali regional untuk teknik
BEMD dapat dihasilkan dengan mengambil beberapa IMF kecil yang dipercaya sebagai residual lalu melakukan penjumlahan untuk IMF yang tersisa. Ini terlihat berbeda jika dibandingkan dengan metode moving average karena dalam metode BEMD jenis regional masih dapat didekomposisi (diuraikan) ke dalam beberapa anomali lainnya.

Hasil dari penelitian ini, IMF 1 dan IMF 2 memperlihatkan satu kesatuan struktur sehingga dapat diduga IMF 1 dan IMF 2 muncul dari satu bodi kontinum yang memiliki struktur pada kedalaman atau pelamparannya. $\mathrm{H}$ al yang sama dapat diamati pada IMF 3 dan IMF 4 yang memiliki hubungan struktural satu sama lain. Struktur yang muncul pada IMF 3 dan IMF 4 tidak teramati pada IMF selainnya. Begitu juga dengan IMF 5 dan IMF 6 (trend global) masing-masing menunjukkan keunikan anomali. Perlu diperhatikan, penyebutan trend global sebagai IMF 6 sebenarnya melanggar definisi IM F, tetapi ini dilakukan hanya untuk memudahkan penyebutan, maka keduanya dipersamakan.

Pemisahan dengan resolusi tinggi semacam ini dapat membantu dalam pemilihan anomali yang akan dianalisis pada tahapan pengolahan lanjut atau diinterpretasi hingga pemodelan. A nomali yang berasal dari IMF 1 dan IMF 2 dapat dijumlahkan kembali untuk dimodelkan. A tau anomali IM F tersebut langsung dianalisis strukturnya untuk delineasi sesar atau satuan geologi. Begitu juga dengan pasangan IMF 3 dan IMF 4, IMF 5, dan IMF 6. Pemilihan kombinasi manapun dari IMF itu tidak akan melanggar apa pun, sehingga ada kebebasan dalam analisis menyesuaikan kebutuhan interpretasi. 


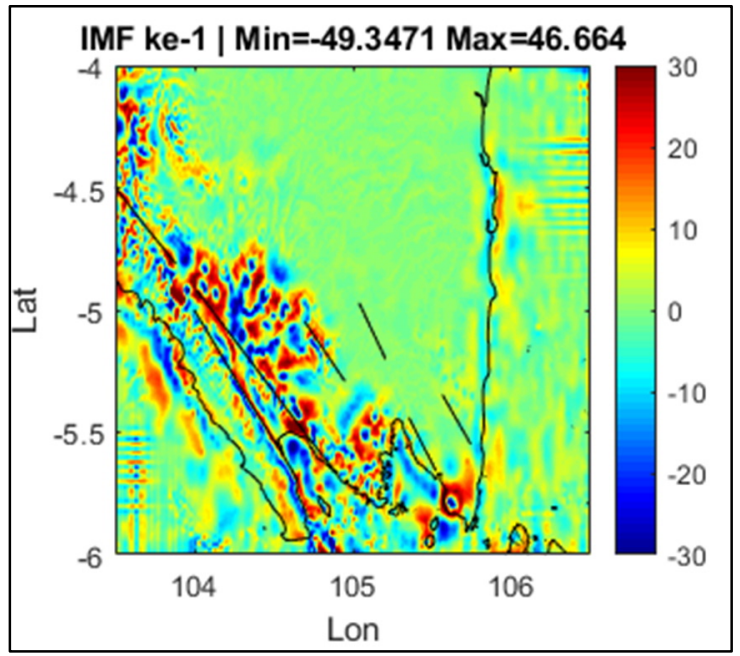

Gambar 8. IMF 1 (1 residual anomaly).

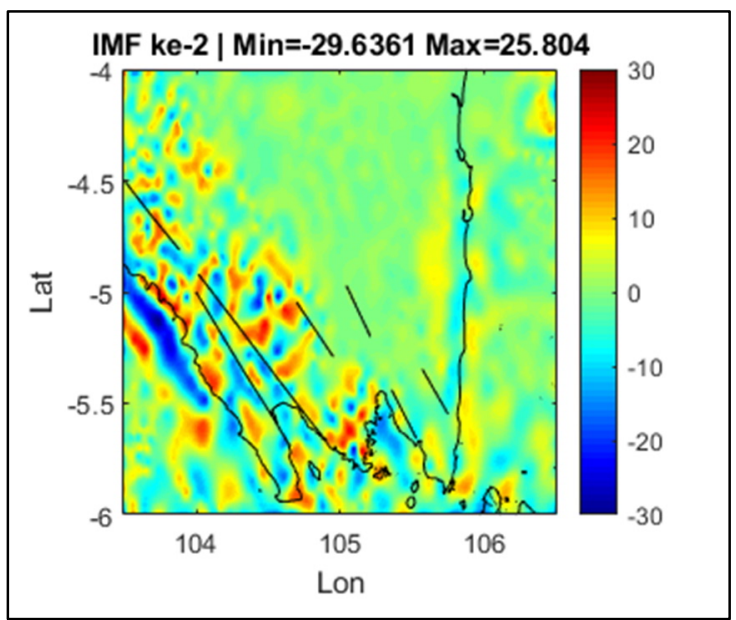

Gambar 9. IM F 2 (2 ${ }^{\text {nd }}$ residual anomaly).

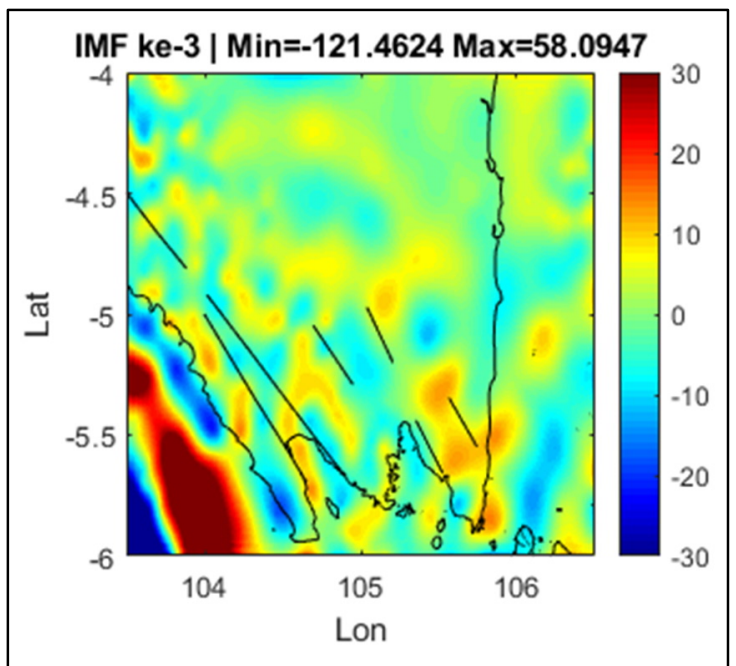

Gambar 10. IM F 3 (3 $3^{\text {rd }}$ residual anomaly).

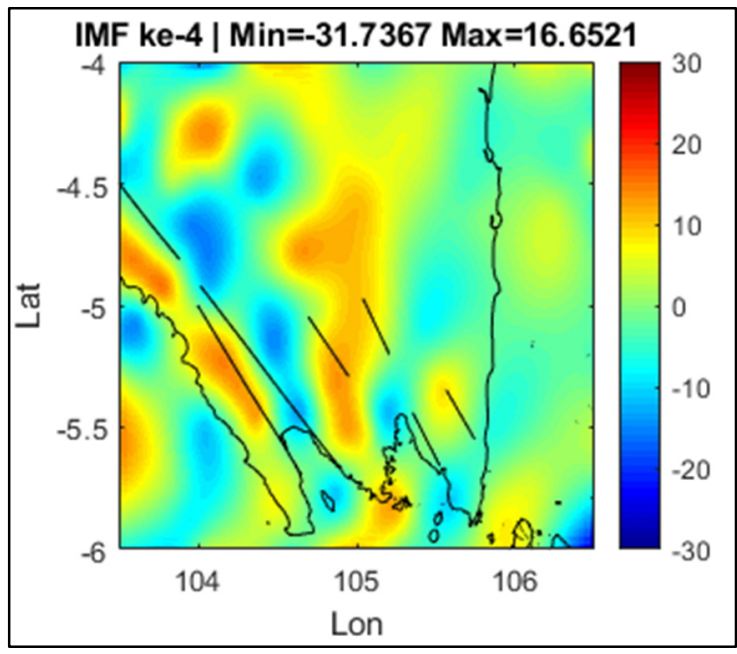

Gambar 11. IM F 4 (global trend/regional anomaly).

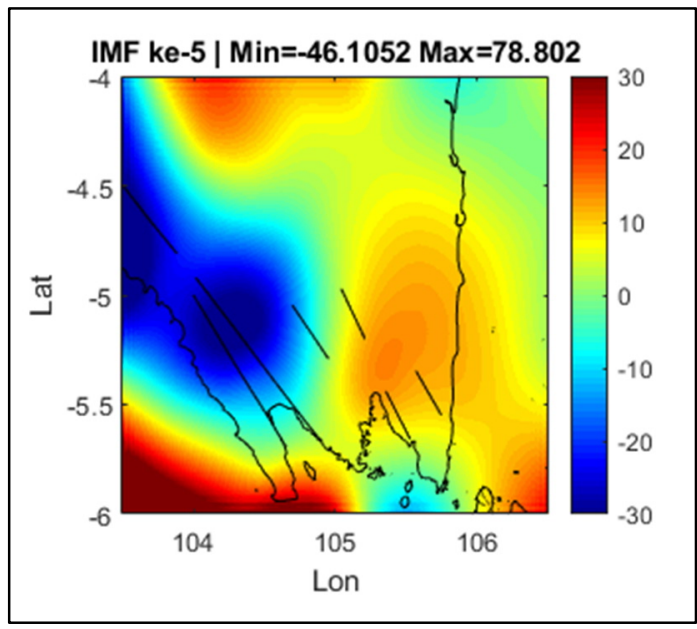

Gambar 12. IM F 5 (global trend/regional anomaly).

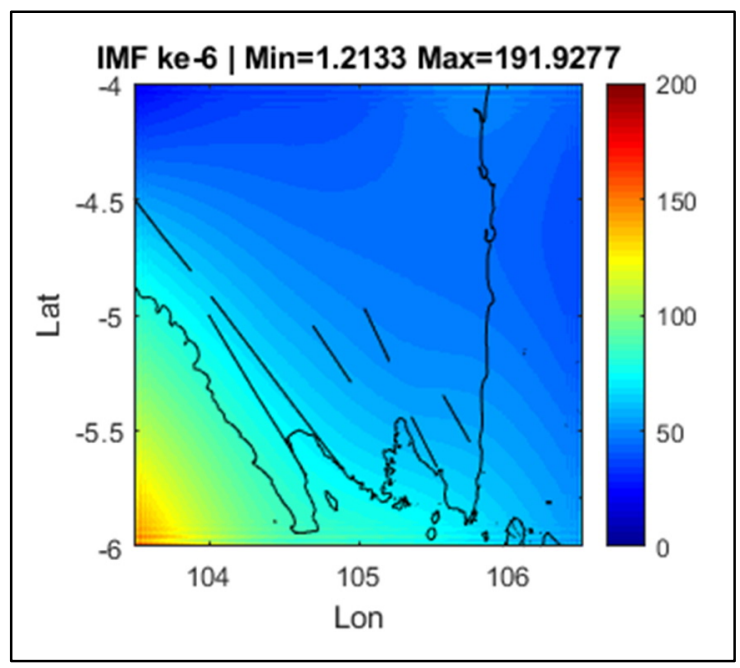

Gambar 13. IM F 6 (global trend/regional anomaly). 
Sebagai contoh, IMF 1 dan IMF 2 dapat dianggap sebagai anomali residual terdangkal karena tidak memiliki trend lokal dan memiliki panjang gelombang terkecil. Kesamaan struktur intrinsik anomali keduanya mengindikasikan bahwa kedua IMF tersebut berasal dari satu bodi yang sama atau paling tidak masih saling berhubungan. Maka, untuk pemodelan dekat permukaan yang berhubungan dengan anomali residual, kita dapat menjumlahkan hasil IM F 1 dan I M F 2.

\section{KESIMPULAN}

Pemisahan anomali CBA dengan menggunakan BEMD berhasil diaplikasikan pada data gayaberat di kawasan Lampung dan sekitarnya. Hasil pemisahan memberikan beberapa tingkat anomali residual maupun anomali regional. Setiap anomali tersebut dapat dianalisis secara terpisah maupun bersama-sama. BEMD bekerja dengan menghilangkan trend lokal dari data gayaberat dan mampu mengekstrak anomali lokal di setiap lokasi. Anomali yang dihasilkan memiliki karakteristik detail dan lengkap. Dari segi algoritma, BEMD dapat dianalogikan dengan moving average dengan ukuran window lokal yang adaptif dan dilakukan berulang kali pada data.

IMF yang dihasilkan tidak mewakili secara pasti periode osilasi tertentu, tetapi dari IMF tersebut mampu diperoleh beberapa tingkat osilasi lokal yang memiliki makna fisis. Ini memungkinkan untuk interpretasi IM F mudah dilakukan. Setiap hasil IMF bisa merepresentasikan anomali yang terpisah satu sama lain sehingga sangat membantu pada pengolahan dan interpretasi struktur geologi bawah permukaan.

Perbedaan utama BEMD dan metode lainnya adalah pada teknik yang digunakan. BEMD menganalisis data dari aspek empirik sehingga kelemahannya adalah kekurangan dasar matematis, semetara metode-metode pemisahan anomali yang lain menggunakan pendekatan matematis dengan teori yang kuat. $N$ amun, hal ini justru menjadi keunggulan pada BEMD untuk mampu meresolusi data tanpa terbatasi oleh parameter matematis. Dengan kata lain, cara kerjanya yang nonparametrik ini memungkinkan BEMD untuk berhasil memisahkan anomali dengan resolusi yang sangat tinggi. Selain itu, BEMD dapat melakukan pemisahan yang lebih sempurna antara anomali-anomali yang muncul pada data. $\mathrm{H}$ al ini terlihat jelas dari eksperimen yang diterapkan pada data CBA di daerah Lampung.

\section{UCAPAN TERIMA KASIH}

Penulis mengucapkan terima kasih kepada reviewer atas komentar dan masukannya yang membangun.

\section{DAFTAR PUST AKA}

AI-Rahim, A. (2016). Separating the gravity field of Iraq by using bidimensional empirical mode decomposition technique. Arabian Journal of Geosciences, 9. https://doi.org/10.1007/s12517015-2118-7

Battista, B. M., Knapp, C., M cGee, T., \& Goebel, V. (2007). Application of The Empirical Mode Decomposition and Hilbert-Huang Transform to Seismic Reflection Data. Geophysics, 72(2), H29-H37.

Bekara, M., \& Van der Baan, M. (2009). Random and Coherent Noise Attenuation by Empirical Mode Decomposition. Geophysics, 74(5), V89V98.

Cooper, S. M., Tianyou, L., \& M bue, I. N. (2010). The Empirical M ode Decomposition (EMD), A N ew Tool for Potential Field Separation. Journal of A merican Science.

Firdaus, R., \& Ekawati, G. M. (2016). I solating Earth's Surface Gravity Body Anomaly from Crust-Regional Anomaly Using Empirical Method. Proceeding SEACG.

Han, J. J., \& Van der Baan, M. (2013). Empirical Mode Decomposition for Seismic TimeFrequency Analysis. Geophysics, 78, 09-019.

Hasan, \& Pierce. (2008). Empirical Mode Decomposition (EMD) of Potential Field Data: Airborne Gravity Data as an Example. In CSEG RECORDER. 
Huang, J. W., \& Milkereit, B. (2009). Empirical Mode Decomposition Based Instantaneous Spectral Analysis and its Applications to Heterogeneous Petrophysical Model Construction. CSPG CSEG CW LS Convention, 205-210.

Huang, J., Zhao, B., Chen, Y., \& Zhao, P. (2010). Bidimensional empirical mode decomposition (BEMD) for extraction of gravity anomalies associated with gold mineralization in the Tongshi gold field, Western Shandong U plifted Block, Eastern China. Computers \& Geosciences, 36, 987- 995. https://doi.org/10.1016/j.cageo.2009.12.007

H uang, N. E., Shen, Z., Long, S. R., W u, M . C., Shih, H. H., Zheng, Q., Yen, N. C., Tung, C. C., \& Liu, H. H. (1971). The Empirical Mode Decomposition and The Hilbert Spectrum for Nonlinear and Non-Stationary Time Series Analysis. Proceedings of the Royal Society A: Mathematical, Physical and Engineering Sciences. Vol. 454, 903-995.

Linderhed, A. (2002). 2D Empirical Mode Decompositions in The Spirit of Image Compression. Proc. SPIE 4738.

M a, M., W ang, C., Li, X., Gao, Q., Gong, W., \& Shi, S. (2019). Aeromagnetic anomalies interpretation based on improved bidimensional empirical mode decomposition
(BEM D) and RGB composition. IOP Conference Series: Earth and Environmental Science, 237, 52002. https://doi.org/10.1088/17551315/237/5/052002

M andal, A., Niyogi, S., \& Ghomsi, F. (2017). A comparative study on trend surface analysis (TSA), wavelet filtering and bi-dimensional empirical mode decomposition (BEMD) for gravity anomaly separation. 1791-1796. https://doi.org/10.1190/segam2017-17780222.1

Nunes, J. C., Niang, O., Bouaoune, Y., Deléchelle, E., \& Bunel, P. (2003). Bidimensional Empirical Mode Decomposition Modified for Texture Analysis.

Pei, Y., Wu, Y.-G., \& Jia, D.-C. (2012). Gravity Anomaly Separation based on Bidimensional Empirical Mode Decomposition. Research Journal of Applied Sciences, Engineering and Technology, 4.

Sandwell, D. T., M üller, R. D., Smith, W . H ., Garcia, E., \& Francis, R. (2014). New Global Marine Gravity Model from CryoSat-2 and Jason-1 Reveals Buried Tectonic Structure. Science, 346(6205), 65-67.

Telford, W. M., Geldart, L. P., \& Sheriff, R. E. (1990). Applied Geophysics (2nd ed.). Cambridge University Press. https://doi.org/10.1017/CB09781139167932 